\title{
NEDD4-Binding Protein 2
}

National Cancer Institute

\section{Source}

National Cancer Institute. NEDD4-Binding Protein 2. NCI Thesaurus. Code C147869.

NEDD4-binding protein 2 (1770 aa, $199 \mathrm{kDa}$ ) is encoded by the human N4BP2 gene.

This protein plays a role in DNA modification. 